'civilization'. Prehistoric people did many weird and wonderful things; the way to read this book is as an entertaining and enlightening account of prehistory's greatest hits. John Robb is in the Department of Archaeology, University of Southampton, Southampton SO17 1BF, UK.

\section{Happy endings?}

\section{Last Rights: The Struggle over the Right to Die}

by Sue Woodman

Plenum Trade: 1998. 293 pp. \$26.95

\section{John Galloway}

"It is silliness to live when to live is torment; and then have we a prescription to die when death is our physician." These words, spoken by Roderigo in Othello, are the mainspring for Last Rights, Sue Woodman's history of 'right-to-die' movements. The title is not just a neat play on words, but goes straight for the jugular. Last rights, not last rites; end of life decisions by doctors have replaced dying with the 'comfort of clergy'. The secular has elbowed aside the spiritual. Why is there still an issue? Roderigo's words seem uncontroversial. The problem now is that modern medicine can keep people alive beyond their 'sell-by date'. On the one hand, people are kept physically alive long after their personalities have been destroyed; on the other, some with their mental faculties intact live lives of dependency and pain.

In reality, 'right-to-die' movements are about the legal right not to be kept alive at all costs, and in extremis the right to be killed or helped to commit suicide. Put like this, there are clearly issues. Euthanasia is almost universally illegal, but the line between killing and not keeping alive is one that is easily crossed. For many people, removing a feeding tube from someone on life-support is not so different from giving an 'overdose' of morphine. As a result, medical institutions have often refused to withdraw life-support without court sanction.

Courts tend to uphold the opinions of doctors and their medical institutions against the wishes of patients and their families. Woodman points out that it was not until the Patient Self-Determination Act in 1991 that US federal legislation upheld patients' wishes against those of doctors or medical institutions. This may have been triggered by the Nancy Cruzan case. Severely injured in a car crash, Nancy was kept on life-support for eight years until a judge agreed there was 'clear and convincing' evidence that she would not have wished to live in a 'vegetable state'.

A popular measure, encouraged in the United States by the Hemlock Society, is the 'living will'. This enables people to make decisions about their medical treatment while of 'sound mind' to cover events when they may not be. Despite the belief that such wills are legally binding, Woodman claims they have often been set aside by doctors.

'Right-to-life' movements have mobilized in opposition to any attempts to legalize euthanasia and physician-assisted suicide. Spearheaded, not surprisingly, by the Catholic Church, they have been supported by organized medicine. Doctors do not wish to be openly associated with death rather than life. Woodman recounts the British Euthanasia Society's failed attempts in the 1930s to have the practice legalized. The Royal Physician, Lord Dawson, argued then that legalizing euthanasia was unnecessary because good physicians already helped their patients die. However, the desirability of doctors acting secretly, above or outside the law, has to be questioned.

In the Netherlands until recently, euthanasia and physician-assisted suicide were illegal, but nevertheless practised with increasing openness. The government would not legalize either, but only prosecuted when doctors failed to abide by strict guidelines. However, fears that the entente between law and medicine was being abused resulted in a series of national studies. The first was commissioned in $1990-91$ by a committee chaired by the Attorney-General of the Dutch supreme court and led to new procedures for reporting end-of-life decisions. Further studies were published in 1996 and 1997, which showed little change from the earlier studies. In 20 per cent of deaths, a decision had been taken to withdraw or withhold treatment. Ten per cent had followed drugs given to relieve pain. Less than 3 per cent resulted from euthanasia, and another 3 per cent from physician-assisted suicide. This type of reliable empirical research about 'end-of-life' decisions achieves two ends. It provides an evidential base for ethical discussion and it brings endof-life decisions into the open. Openness and transparency must be the best guards against abuse.

Woodman has written a readable book about this legal and ethical minefield. Her journalistic style will not appeal to everyone. However, the book has the advantage of starting with the deaths of real people from which she attempts to draw general conclusions. The result is more powerful than starting with abstract ethical principles and applying these to individual cases. Some deaths, like Nancy Cruzan's, are included because they were pivotal in changing the law. Others, like that of Woodman's aunt, are simply an attempt to tell it 'like it is'.

Woodman also introduces us to the other side of the coin of dying - to crusaders like the retired US pathologist, Jack Kevorkian, who helps people die. Working on the fringes of the law, he has been tried and acquitted several times on charges of unlawful killing. How much of his success in avoiding conviction can be put down to the weakness of the law, and how much to his lawyer, Geoffrey Fieger, is itself a significant question. It reminds us that the law is an imperfect instrument. Enshrining the principle of 'right to die' in statute is one thing; implementing it in a way that delivers what the 'right-to-die' movements want would undoubtedly be another.

John Galloway is at the Eastman Dental Hospital, 256 Grays Inn Road, London WC1X 8LD, UK.

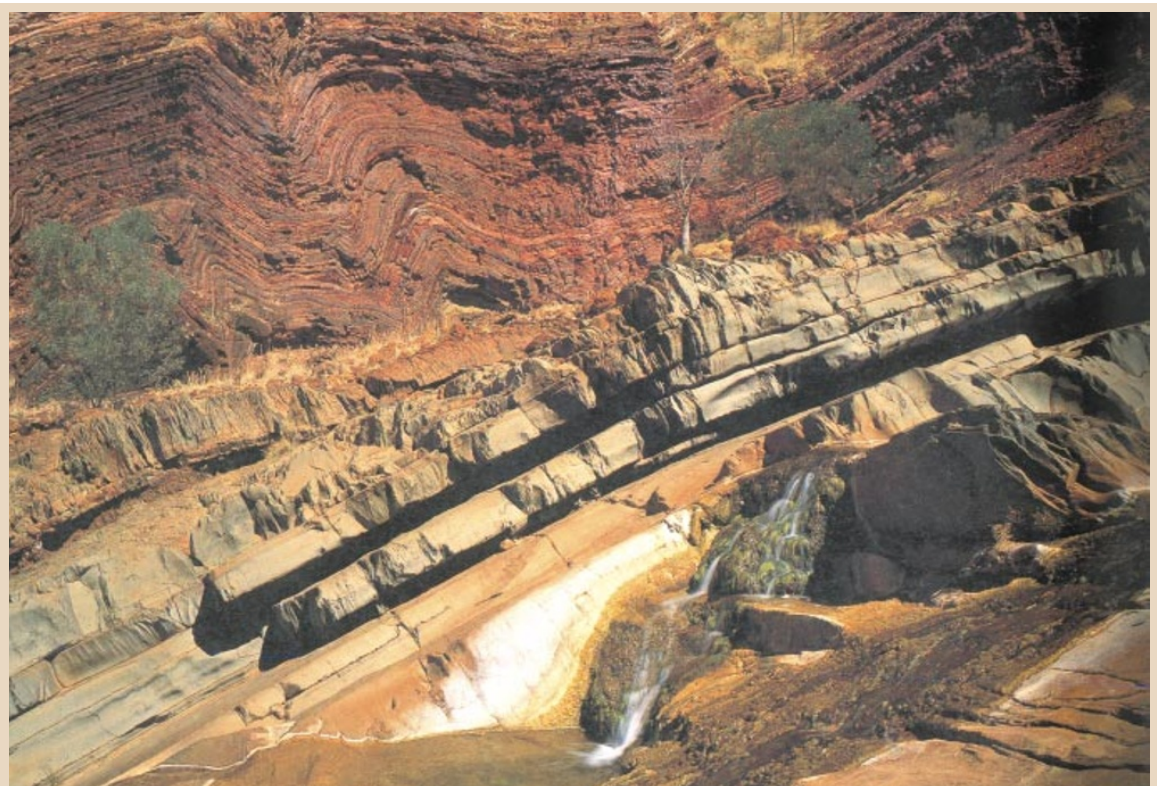

\section{Shaping the Earth}

Our knowledge of the remarkable and complex forces that have created the Earth we see today continues to grow. Simon Lamb and David
Sington look at these forces and their interactions in Earth Story: The Shaping of our World (Princeton University Press, \$29.95). 